\title{
STRATEGI RAYA SRIWIJAYA DAN MELAKA
}

SRIWIJAYA AND MALACCA'S GRAND STRATEGY

\section{Prisca Kiki Wulandari*}

Pusat Matakuliah Pengembangan Kepribadian (MPK)

Universitas Brawijaya

Jalan Veteran Malang 65145 Indonesia

\section{INFO ARTIKEL}

\section{Riwayat Artikel:}

Diterima : 04 Juni 2020

Disetujui : 27 Juni 2020

\section{Keywords:}

geopolitics, geostrategy, historical patterns, national defense

\section{Kata Kunci:}

geopolitik, geostrategi, pola-pola

sejarah, ketahanan nasional

\section{*) Korespondensi:}

E-mail: priscakiki@ub.ac.id

\begin{abstract}
: this study attempted to explore the political strategy of two Malay kingdoms, Srivijaya and Malacca, which was seen from the theory of grand strategy. The library research was used to address the main question of grand strategy from two kingdoms. Malacca seemed to continue how did Srivijaya manage the geopolitical balance in the Straits of Malacca. If Srivijaya sent their embassies to the major kingdoms in Asia, Malacca did the same. Malacca also negotiated the friendly relations to the Pasai and Ming Dynasty of Cina. Social life either during Srivijayan or Malaccan times depended on maritime activities. Both kingdoms initiated an alliance with the seafaring communities, seamen, and pirates, to decrease the trading risk and attracted the merchants to populate both port-cities. These historical patterns are not merely a public memory but an invaluable lesson for national defense for this country.
\end{abstract}

\begin{abstract}
Abstrak: artikel ini berupaya untuk mengeksplorasi strategi politik dua kerajaan Melayu yakni Sriwijaya dan Melaka jika dilihat dari teori strategi raya (grand strategy). Kajian kepustakaan digunakan sebagai metode penelitian untuk menemukan pola-pola strategi raya dari dua kerajaan Melayu. Melaka terlihat meneruskan strategi Sriwijaya mengelola keseimbangan geopolitik di Selat Melaka. Jika Sriwijaya melakukan hubungan diplomasi dengan negerinegeri adidaya di Asia, Melaka juga melakukan hal yang sama. Melaka menjalin kontak dengan penguasa Pasai dan Dinasti Ming, penguasa Cina. Kehidupan masyarakat keduanya sangat bergantung pada kehidupan maritim. Kedua kerajaan bekerja sama dengan orang laut dan bajak laut untuk menekan risiko perdagangan sekaligus menarik pedagang untuk singgah dan berdagang. Pola-pola sejarah yang tampak bukan sekedar memori publik yang datang untuk dilupakan. Akan tetapi, dapat digunakan sebagai pelajaran berharga bagi ketahanan nasional bangsa ini.
\end{abstract}

\section{PENDAHULUAN}

Sejarah adalah pelajaran filosofis dengan berbagai keteladanannya. Pernyataan ini telah menjadi adagium populer sekaligus asumsi dasar sejarah terus dikaji. Sejarah memang sekali terjadi dan tidak mungkin berulang. Akan tetapi, pola-pola sejarah seringkali berulang, begitu pula dengan yang terjadi pada sejarah Indonesia.
Dalam perjalanan sejarah Indonesia, ratu adil telah menjadi motor utama penggerak berbagai pemberontakan di Jawa pada medio abad ke-19. Sebagaimana dijelaskan Kartodirdjo (1989), aktor sejarah yang memimpin berbagai pemberontakan bukan orang yang sama, di tempat yang sama, dan pada waktu yang sama. Akan tetapi, mereka mendapuk dirinya sebagai ratu adil dan mengobarkan semangat pemberontakan. 
Kemunculan ratu adil sepanjang sejarah Indonesia, memiliki pola-pola sejarah yang sama. Pola-pola ini dapat digunakan untuk mengkaji suatu fenomena pada bidang kehidupan, termasuk dalam bidang pertahanan dan keamanan. Kajian pertahanan dan keamanan juga seringkali menggunakan perspektif sejarah. Kajian pertahanan dan keamanan melakukan retrospeksi atas berbagai upaya polis (negara-kota), kerajaan, kekaisaran atau negara dalam menjaga daerah kekuasaannya.

Dengan menggunakan teori strategi raya ( grand strategy), kajian pertahanan dan keamanan bukan hanya melihat suatu negara dari kekuatan militernya saja tetapi juga aspek diplomasi dan birokrasi politik untuk menangkal berbagai ancaman eksternal sekaligus mempertahankan kekuasaannya dan memperoleh keuntungan ekonomi (Wey \& Harun, 2018). Teori strategi raya telah banyak dikaji oleh para peneliti terdahulu. Peneliti terdahulu mengkaji Polis Athena (Strassler, 1996), Kekaisaran Romawi (Luttwak, 1996), Kekaisaran Romawi Timur (Luttwak, 2009), Kekaisaran Habsburg (Parker, 1998), dan Kesultanan Melaka (Wey \& Harun, 2018). Jika Melaka dianggap sebagai kelanjutan dari Sriwijaya maka tulisan akan mencoba memakai beberapa premis dari teori strategi raya sebagai indikator untuk mengeksplorasi kebijakan politik kedua kerajaan.

\section{METODE}

Kajian ini menggunakan metode penelitian kepustakaan untuk menjawab rumusan masalah utama kajian ini yakni strategi raya yang diterapkan oleh Sriwijaya dan Melaka. Terdapat empat langkah yang dilakukan. Langkah pertama adalah menyiapkan alat perlengkapan berupa pensil, pulpen, dan kertas catatan. Langkah kedua adalah menyusun bibliografi kerja. Selanjutnya yang dilakukan adalah mengatur waktu penelitian. Setelah itu yang dilakukan adalah membaca dan membuat catatan penelitian.

Penyusunan bibliografi kerja dilakukan dengan membaca beberapa referensi utama seperti karya Wolters (1966) dan Meilink-Roelofzs (1962). Akan tetapi, penelitian ini tentu saja membutuhkan waktu untuk membaca berbagai buku yang relevan. Dengan bantuan catatan penelitian, peneliti membaca sambil mencatat untuk mendapatkan data. Selanjutnya, peneliti perlu membuat catatan ulasan kritis tentang sebuah buku yang paling relevan dengan riset (Zed, 2008). Pada tahap terakhir, peneliti melakukan analisis dan sintesis.

Peneliti menggunakan analisis isi teks dengan mengajukan pertanyaan terkait isi sebenarnya dari sebuah pernyataan dalam teks, adanya prasangka (bias) dalam tulisan pengarang, tujuan pengarang membuat, seberapa yakin pengarang dalam membuat pernyataan dalam teks. Setelah itu, peneliti berupaya mengombinasikan hasil analisis dalam struktur konstruksi yang mudah dimengerti (Zed, 2008). Hasil analisis tersebut kemudian dituangkan melalui tulisan ini.

\section{HASIL DAN PEMBAHASAN}

\section{Strategi Raya Kedatuan Sriwijaya}

Sriwijaya disebut sebagai salah satu pondasi semangat nasionalisme Bangsa Indonesia. Sriwijaya bersama Majapahit disebut sebagai suatu kerajaan nasional sekaligus menjadi pondasi imajinasiimajinasi persatuan bagi para nasionalis untuk bergerak. Anas et al. (2017) mengungkapkan bahwa Kerajaan Sriwijaya adalah kerajaan pertama yang mampu mengusung pandangan dasar tentang kesatuan pada penyelenggaran sistem kerajaan.

Nilai-nilai kesatuan pada masa itu secara implisit memberikan penguatan pemahaman pada sila ketuhanan bahwa persatuan sebuah bangsa akan terjadi apabila memiliki raja yang cakap dan religius. Kemajuan Sriwijaya dalam bidang politik dan perdagangan juga tidak dapat dipisahkan dari perkembangan agama Buddha. Hal ini juga didukung dengan sifat kosmopolit dan keterbukaan dari Sriwijaya dalam menerima hal-hal baru dari luar sehingga roh internasionalisme dari bangsa Indonesia juga tetap menjadi pegangan.

Penggunaan Sriwijaya sebagai lambang nasionalisme adalah upaya untuk mengikis kritik-kritik tentang dominasi Jawa (dengan digambarkannya Majapahit) dalam mengimajinasikan suatu bangsa (Rizal, 2017). Setidaknya Sriwijaya telah meletakkan semangat nasionalisme melalui premis-premis kosmopolitanisme yang tercermin bukan hanya dari interaksi multi etnis perdagangan global tetapi juga dari proses sinkretisme kehidupan dalam perjalanan sejarah (Beros, 2016; Lombard, 1996). Tentunya hal ini menjadi abstrak untuk ditelisik kembali bagaimana kontinuitas kosmopolitanisme Sriwijaya 
mengingat adanya gap waktu yang terbentang, sekitar 13 abad, antara eksistensi Sriwijaya yang dimulai dari abad ke-7 dan kebangkitan nasional pada permulaan abad ke-20.

Dalam rentang waktu tersebut, bukan hanya berbagai perubahan telah terjadi tetapi juga berbagai kontinuitas kehidupan juga masih tampak sebagai representasi pewarisan budaya dari satu generasi ke generasi selanjutnya. Pada konteks ini, berbagai budaya maritim Sriwijaya tetap dipergunakan baik oleh bangsa Melayu sendiri (Kesultanan Melayu Melaka) maupun oleh bangsa asing (Villiers dan Earle, 1990; Budisantoso, 2006). Penulis berupaya untuk membatasi bahasan ini pada kontinuitas budaya maritim Sriwijaya ke Melaka.

Batasan tersebut diterapkan karena dinilai tidak terlalu jauh dari segi temporal, jika ingin melihat warisan budaya maritim Sriwijaya dengan mengetengahkan eksistensi Kesultanan Melayu Melaka. Bahkan, kehancuran Sriwijaya dapat dikatakan sebagai titik awal kemunculan Melaka.

Pendiri Melaka, Parameswara masih memiliki hubungan darah dengan penguasa Sriwijaya. Hal ini yang kemudian memunculkan suatu hipotesis bahwa Kesultanan Melaka tidak lain adalah keberlanjutan dari kerajaan Sriwijaya. Menurut Andaya dan Andaya (1982) Melaka berasal dari Palembang, dimana pelabuhan besar Sriwijaya berada dan berkembang pesat. Hal ini kemudian menjadi sebuah legitimasi dan kepercayaan diri yang tinggi bagi para penguasa Melaka bahwa mereka memiliki hubungan langsung dengan Sriwijaya. Perpindahan dari Palembang ke Melaka dapat dilihat sebagai bagian dari kelanjutan dalam sejarah bangsa Melayu. Sriwijaya sebagai kerajaan maritim memiliki setidaknya dua karakteristik.

Pertama, Sriwijaya memiliki suatu birokrasi politik yang membuatnya mampu mengelola daerah strategis yang dimilikinya. Sebagai salah satu negara tradisional, kekuasaan kerajaan tetap berpusat pada wibawa seorang raja. Raja berperan penting dalam pengambilan keputusan dan mengawasi kinerja pemerintahan terutama dalam mengontrol keseluruhan jejaring dan aliansi perdagangan secara langsung (Christie, 1995; Claessen, 1995). Birokrasi kerajaan Sriwijaya, seperti dijelaskan Kulke (1993) dan Poesponegoro dan Notosusanto (2010), menganut sistem kedatuan dimana pusat kerajaan baik ketika bermukim di Palembang maupun Jambi (Wolters, 1966), memiliki posisi penting dalam mengontrol tiap-tiap mandala yang berada dibawah kekuasaan para datu.

Para datu biasanya diisi oleh keluarga kerajaan seperti putra mahkota (yuwaraja), putra raja kedua (pratiyuwaraja), putra raja ketiga (rajakumara), dan putra raja keempat (rajaputra). Kemudian diikuti oleh penguasa lokal (bhupati), komandan militer (senapati), pegawai perkantoran (nayaka), sekretaris atau pengurus harta raja (pratyaya), hakim raja (dandandyaka), juru tulis (Kayastha), arsitek bangunan keagamaan (Sthapaka), nahkoda (puhawam), pengawas dan pengorganisasian perdagangan termasuk bekerjasama dengan bajak laut (Tuha An Vatakuurah). Sebagai kerajaan maritim, posisi Tuha An Vatakuurah sangatlah vital. Mereka didukung oleh kekuatan militer (Wade, 2009) sekaligus mengandalkan peran para bajak laut untuk mengawasi dan memastikan keamanan perdagangan di sekitar Selat Melaka. Keamanan dalam berdagang inilah yang menarik para pedagang Arab, India, dan Cina untuk berlayar dan singgah di Palembang sebelum melanjutkan perjalanan ke India atau Cina (Soleh, 2015).

Kedua, Sriwijaya sebagai kerajaan maritim menjadi titik temu para pedagang untuk melakukan jual beli. Pembentukan Sriwijaya sebagai pusat perdagangan tidak dapat dilepaskan dari ekspansi Sriwijaya ke daerah-daerah strategis (Jambi, Lampung, Pulau Bangka, Ligor, dan Kedah) terutama untuk menyokong hegemoni Sriwijaya atas Selat Sunda dan Selat Melaka (Pradhani, 2017; MeilinkRoelofsz, 1970). Sebelum kekuasaan Sanjaya dan Hinduisme menguat di Jawa pada awal abad ke-9, Jawa berada dibawah kekuasaan Sailendra hingga akhir abad ke-8 masehi.

Pada masa selanjutnya, hubungan Sriwijaya dan Jawa cenderung tidak menentu dan Kerajaan Medang di bawah Dharmawangsa Teguh melakukan invasi ke Sriwijaya pada 992 sebelum dipukul mundur pada 997 (Wade, 2009). Akan tetapi, kondisi ini tidak menghentikan ekspansi Sriwijaya ke pelabuhan-pelabuhan penting di Sumatra maupun ke Semenanjung Melayu (Wales, 1978). Setelah menguasai berbagai pelabuhan penting, struktur perdagangan Sriwijaya dapat terlihat. Terdapat tiga level dalam jejaring perdagangan Sriwijaya: (1) pelabuhan pusat Sriwijaya yang berada di Palembang; (2) pelabuhan sub regional; dan (3) 
pelabuhan-pelabuhan kecil yang bertugas untuk menyediakan konsumsi. Berbagai pelabuhan yang berada di bawah Sriwijaya diantaranya adalah Pelabuhan Kra, Chaiya, Kedah, Jambi-Malayu, Lampung, Kota Cina, Sungai Emas, Kampar, Barus, dan Lamuri.

Pelabuhan-pelabuhan tersebut diharuskan membayarkan upeti secara reguler pada raja dan bertugas untuk mencegah segala ancaman yang datang pada aktivitas perdagangan internasional di Palembang (Wade, 2009). Selain itu, mereka juga mengirim para pedagangnya untuk berdagang dan berdiplomasi di pelabuhan-pelabuhan strategis lainnya. Hal ini terjadi karena Sriwijaya gencar melakukan berbagai diplomasi dalam memperkuat jaringan perdagangan global (Pradhani, 2017) Sriwijaya telah memiliki jaringan komunikasi dengan Pantai Koromandel (Hall, 1955). Dengan adanya informasi dari Prasasti Nalanda (860 M) bahwa pendirian Vihara oleh Balaputradewa (berkuasa sekitar 835-860) mengindikasikan adanya hubungan baik dengan Bengala dan tentunya adanya kontak perdagangan pula.

Kunjungan pedagang Sriwijaya ke Cina juga semakin memperkuat jaringan perdagangan Sriwijaya. Dinasti Song (960-1279) yang berkuasa di Cina telah menjalin hubungan dagang dari abad ke-10 hingga abad ke-12. Setelah duta Sriwijaya mendarat di pusat kerajaan Song, Sriwijaya kemudian membangun Vihara untuk menghormati penguasa Dinasti Song pada permulaan abad ke-11, yang kemudian berlanjut dengan sokongan 30,000 Tael Tembaga untuk memperbaiki suatu vihara di GuangZhou. Peran dari pedagang baik dari Sriwijaya dan Song telah memperkuat pertalian mereka (Wade, 2009; Poesponegoro \& Notosusanto, 2010). Uraian di atas menunjukkan bahwa Sriwijaya memiliki jaringan yang kuat dalam perdagangan.

\section{Strategi Raya Kesultanan Melaka}

Kedua karakteristik kemaritiman Sriwijaya juga terlihat dalam eksistensi Melaka sebagai pusat politik dan perdagangan. Melaka seolah-olah berkembang dan mencapai masa keemasannya dengan melanjutkan apa yang telah dilakukan oleh Sriwijaya. Tidak banyak sumber lokal yang tersedia mengenai Kesultanan Melayu Melaka. Akan tetapi, keberadaan Sejarah Melayu dapat membantu memberikan pintu masuk bagaimana pendirian, perkembangan, dan kejatuhan Kesultanan Melayu Melaka.

Menurut naskah tersebut, Melaka didirikan oleh Raja Iskandar Syah setelah terusir dari Tumasik (Singapura) akibat serangan dari Jawa. Menurut Ahmad (1984) tidak banyak informasi yang disediakan terkait Raja Iskandar Syah selain dia adalah anak dari Raja Pasai. Pires (2010) memberikan informasi yang sangat berharga dengan bertanya pada petualang dari Jawa. Pendiri Melaka bukanlah Raja Iskandar Syah tetapi Parameswara (1344-1414, berkuasa di Melaka dari 1402 hingga 1414).

Parameswara adalah putra dari penguasa Palembang yang pada waktu itu masih menjadi vasal dari Kerajaan Singhasari (hasil ekspedisi pamalayu tahun 1275). Parameswara menikahi keponakan perempuan Batara Tumapel yang bernama Parameswari. Segera setelah ayahandanya wafat, Parameswara mulai menunjukkan keinginannya untuk berdaulat dan melepaskan diri dari kekuasaan Jawa (Majapahit yang merasa sebagai kelanjutan Singhasari dan ingin mendapatkan kembali vasal dari Singhasari). Penguasa Jawa tidak bergegas lama kemudian menyerang Palembang dan terus memburu Parameswara. Pelarian Parameswara berakhir di Tumasik (Singapura) dan kemudian dia membunuh penguasa Tumasik sekaligus menantu dari Raja Siam. Raja Siam yang marah kemudian menyerang Parameswara hingga kemudian dia melarikan diri ke Sungai Muar, tempat dimana kemudian dia mendirikan Melaka.

Dengan mengandalkan para pengikut setianya, Parameswara mulai membabat hutan dan mulai berinteraksi dengan para nelayan yang terlebih dahulu berada disekitar hulu Sungai Muar. Parameswara juga berhasil mengambil hati para orang laut yang kemudian menempati posisi penting dalam navigasi perairan di sekitar Selat Melaka. Orang laut tersebut dapat ditemui dengan mudah di sekitar Singapura dan Palembang. Mereka sangat berharap Melaka menjadi tempat yang nyaman bagi mereka berlindung saat di darat. Uniknya, para orang laut ini akan mengabdi para pewaris tahta Sriwijaya yang tidak lain adalah tempat darimana Parameswara berkuasa (Pires, 2010). Setelah Parameswara meninggal, dia digantikan oleh anaknya yang bernama Xaquem Darxa atau yang dikenal dengan Meghat Iskandar Syah. 
Sultan kedua inilah yang berupaya membina hubungan baik dengan Siam dan Jawa. Pires (2010) mengungkapkan bahwa setelah memeluk Islam, Meghat Iskandar Syah menjadi sekutu Sultan Pasai sebagai bagian dari strategi politiknya untuk membesarkan Bandar Melaka. Pires (2010) tidak menyebutkan siapa pengganti Xaquem Darxa dan hanya menyebutkan Modafarxa kemudian menjadi sultan setelah membunuh keponakannya sendiri. Modafarxa kiranya adalah Sultan Muzaffar Syah yang menjadi sultan setelah melewati suksesi berdarah. Akan tetapi, Sejarah Melayu memberikan keterangan bahwa selain sultan yang dibunuh, masih terdapat satu sultan lagi yakni Sultan Muhammad Syah.

Pada masa Sultan Muhammad (1422-1444), birokrasi politik Melaka mulai terbentuk. Pada masa tersebut, Sultan menempati posisi penting dan dibantu oleh seorang Bendahara bergelar Seri Wak Raja, Penghulu Bendahari bergelar Seri Nara Diraja, Hulubalang bergelar Seri Bija Diraja, Temenggung, Laksamana, dan Syahbandar. Dengan struktur politik yang mulai terbangun, Melaka mulai melakukan ekspansi hingga ke Ujung Karang ke arah barat dan hingga Trengganu ke arah timur (Ahmad, 1984). Setelah Sultan Muhammad Syah meninggal, tahta diduduki oleh anaknya yang bergelar Sultan Abu Syahid (1444-1445).

Abu Syahid tidak begitu cakap dalam memerintah sehingga kekuasaannya dibawah kontrol Raja Pekan. Hal ini yang membuat Raja Kassim, saudara Sultan Muhammad, untuk memberontak dan membunuh Raja Pekan dengan bantuan segenap pejabat kesultanan yang muak dengan hegemoni Raja Pekan. Setelah berhasil membunuh Raja Pekan dan menurunkan saudaranya dari tahta, Raja Kassim menaiki tahta dengan gelar Sultan Muzaffar Syah (1445-1456).

Pada masa Sultan Muzzafar, kitab undangundang dibuat (Ahmad, 1984). Jika benar kitab yang dimaksud adalah Undang Undang Melaka (The Laws of Malacca) maka birokrasi yang ada sebelumnya mulai untuk disempurnakan dan dibakukan. Salah satu bagian yang menarik dari undang-undang ini adalah adanya undang undang laut (the Maritime Code). Keberadaan undang-undang tersebut menggarisbawahi siapa yang berkuasa di lautan. Jika Sultan Melaka yang menguasai daratan maka ketika berdagang via kapal laut maka nahkodalah yang menjadi penguasa (Raffles, 1879). Setelah berkuasa selama 42 tahun, anak sultan kemudian naik tahta dengan gelar Sultan Mansur Syah.

Pada masa Sultan Mansur, ekspansi Melaka semakin kentara. Selain melancarkan serangan Inderapura, Kampar, dan Siak; Sultan juga membina hubungan baik dengan Raja Gowa (Makasar), Siam, Majapahit, dan Cina. Hubungan diplomasi dengan Gowa dan Siam berjalan dengan baik karena kemampuan komunikasi utusan sultan sedangkan keberhasilan diplomasi dengan Majapahit dan Cina karena keterlibatan sultan sendiri.

Sultan diambil menantu oleh Raja Majapahit dan Cina sekaligus menguatkan bahwa perkawinan politik adalah hal yang wajar dilakukan untuk menjaga kedaulatan Melaka (Ahmad, 1984). Setelah Raja Muhammad diusir karena membunuh anak Bendahara, sang sultan kemudian murka dan menjadikan putra mahkota sebagai sultan di Pahang sedangkan yang menggantikan perannya sebagai sultan adalah Raja Ahmad dengan gelar Sultan Alauddin Riayat Syah.

Pada masa Sultan Alauddin, Raja Maluku (Tidore) datang ke Melaka setelah daerahnya dirampas oleh Prajurit Kastila (Spanyol). Dia berupaya untuk menggalang bantuan guna memukul mundur Spanyol dari Maluku (Ahmad, 1984). Ketika kekuasaan Sultan Alauddin berakhir, maka anaknya dengan gelar Sultan Mahmud menaiki tahta.

Pada masanya inilah, Bangsa Peringgi (Bangsa Portugis) pertama kali datang dan kemudian datang kedua kalinya untuk menggempur Kesultanan Melaka serta memburu Sultan Mahmud hingga akhir hayatnya. Kemerosotan Melaka bukan hanya karena serangan Portugis tetapi lebih jauh juga diakibatkan dari sisi negatif dari budaya kolusi yang sudah mengakar kuat. Salah satu contohnya adalah perselisihan antar saudagar dapat berpengaruh pada kondisi internal kesultanan.

Suatu saat seorang saudara dari Keling bernama Nira Sura Dewana memiliki permasalahan perdagangan dengan Syahbandar Melaka yang juga berasal dari keling, Raja Mendaliar (Ahmad, 1984). Nira Sura menyadari bahwa dirinya pasti kalah jika masalahnya dibawa ke pengadilan negara. Dia melihat sang syahbandar memiliki harta kekayaan yang melebihinya. Oleh karena itu, dia memberikan sejumlah emas pada Bendahara dan berharap sang bendahara mau untuk membantunya. Akan tetapi, sang syahbandar ternyata begitu dekat dengan 
laksamana. Dengan bantuan Laksamana, mereka kemudian membujuk sultan untuk menghukum bendahara yang telah lalai dalam membuat suatu keputusan yang adil.

Melihat faktor geografis, Melaka menjadi salah satu tempat strategis di Selat Melaka. Melaka dapat dijadikan salah satu pelabuhan yang ideal untuk dijadikan tempat beristirahat sebelum melanjutkan perjalanan baik bagi yang menuju Cina, India, maupun Kepulauan Rempah-Rempah. Dengan keberadaan angin muson yang berhembus musiman maka membuat para pedagang harus menunggu dan berdagang sejenak di Melaka. Namun dengan berjalannya waktu kelak, Melaka menjadi titik temu berbagai pedagang dengan membawa barang dagangan dan membuat komoditas di Melaka melimpah ruah.

Setelah Parameswara mendirikan Melaka, dia mengembangkan kota hingga seolah-olah kota Melaka terbelah menjadi dua dengan keberadaan Sungai Muar (Eredia, 1930). Kerajaan baru ini kemudian mengembangkan perdagangan maritim dan tidak berselang lama, banyak orang yang mengunjungi Melaka untuk melakukan jual beli ikan segar yang menjadi komoditi utama Melaka. Setelah pelabuhan Melaka resmi dibuka, para pedagang dari Koromandel kemudian juga turut menjajakan berbagai pakaian disana. Orang-orang Koromandel inilah yang membantu menarik orang asing untuk datang dan menukarkan emas dan rempah-rempah mereka dengan pakaian.

Berbagai usaha sultan kedua Melaka, Sultan Meghat Iskandar Syah dalam mengembangkan Melaka tidak dapat dipandang sebelah mata. Selain menjalin hubungan dagang dengan Jawa, Sultan memeluk Islam dan bersahabat baik dengan sekaligus menjadi menantu Sultan Pasai. Sultan Pasai kemudian mulai datang untuk berdagang ke Melaka dan demikian pula para saudagar muslim dari Persia, Bengala, dan Arab juga meramaikan perdagangan di Melaka. Sultan memberikan fasilitas yang sangat baik bagi para saudagar yang sekedar berlabuh atau berdagang di Melaka. Dia memberikan tempat untuk tinggal dan beribadah (masjid).

Perdagangan segera tumbuh dengan pesatnya karena para saudagar muslim pada waktu sangat kaya. Sultan mendapatkan keuntungan berlipat. Sikap bijak dan adil yang melekat pada Sultan dan semakin ramainya Bandar Melaka membuat banyak orang dari Sumatra, Singapura, bahkan Orang Laut (menjadi pasukan kesultanan) untuk datang mencari pekerjaan di Melaka. Selain itu, banyak kapal-kapal asing terutama dari Cina yang penasaran untuk singgah ke Melaka (Pires, 2010). Melihat adanya peluang kerjasama untuk mengembangkan perdagangan Melaka-Cina maka Sultan sangat ingin untuk bertemu Kaisar Cina, yang pada waktu itu menjadi tempat bagi Raja Jawa, Pasai, dan Siam mengirimkan upeti tiap tahunnya.

Sultan sendiri juga ingin melakukan hal yang sama dengan mengakui kedaulatan Cina dan mengirimkan upeti tahunannya. Sebagai gantinya Melaka akan mendapatkan perlindungan politik dan militer. Hal ini tentu saja akan memudahkan Melaka ketika memberikan keamanan dan kenyamanan dalam berdagang bagi para saudagar asing (Pires, 2010). Pada masa Sultan Mansur Syah (disebut Pires dengan nama Mansursa), jejaring perdagangan Melaka semakin luas, selain telah menjadikan Inderagiri (penghasil emas), Kampar, Selangor (penghasil timah), Kedah (penghasil timah), Siak, Pulau Bintang sebagai penyedia komoditi dagang dan pelabuhan bayangan. Nama Sultan Melaka menjadi sangat terkenal dan dia banyak menerima surat dan hadiah dari Raja Cambay, Aden, dan Hormuz. Mereka kemudian bermaksud untuk mengirimkan para pedagangnya kesana.

Tidak berhenti disitu, Sultan Mansur juga membina hubungan baik dengan Siam, Majapahit, dan Cina dengan memberikan gajah sebagai hadiah (Pires, 2010; Ahmad, 1984). Orang-orang Melaka menilai Sultan Mansur adalah sultan yang paling adil dan bijaksana daripada para pendahulunya. Dia banyak memberikan kelonggaran pada para pedagang asing terutama pedagang dari Keling. Selain dia melakukan perkawinan politik dengan Putri Pahang sekaligus keponakan dari Raja Siam, Sang sultan juga menikahi dan mengislamkan semua anak perempuan cantik dari para pedagang Persia dan Keling (Pires, 2010). Arah kebijakan politik yang demikianlah yang membuat Sultan Mansur dinilai baik oleh pedagang-pedagang pada masa itu.

Arah kebijakan politik luar negeri Melaka segera berubah ketika dipimpin oleh Sultan Alauddin. Sultan baru tidak lagi melihat kekayaan sebagai tujuan pemerintahannya. Dia merasa lebih penting untuk menangani hidup setelah kematiannya 
kelak. Hal ini yang kemudian membawa Melaka dalam kemerosotannya. Ditambah pengganti dari Sultan Alauddin, Sultan Mahmud hanya mengirim upeti ke Cina dan tidak lagi berdiplomasi dengan Siam maupun Jawa. Sultan Mahmud yakin tanpa hubungan yang baik dengan negara tetangga, Melaka akan tetap menjadi emporium yang kuat. Dugaan tersebut ternyata salah besar, Sultan Mahmud tidak memahami kekuatan asing yang datang. Bangsa Portugis yang sebermula hanya berdagang tidak terlalu direspon oleh Melaka hingga kemudian mereka melancarkan serangan dan meluluhlantakkan Melaka (Pires, 2010). Hal tersebutlah yang kemudian menjadi salah satu pemicu berakhirnya Kerajaan Melaka.

Jika seluruh kerajaan di Indonesia dari awal masehi hingga masa modern, terutama Kerajaan Majapahit, dikaji berdasarkan teori strategi raya maka akan menjadi kajian yang sangat menarik. Pola-pola yang tercipta dalam perubahan dan kesinambungan sejarah kerajaan-kerajaan di Nusantara akan memudahkan bangsa Indonesia untuk melihat geopolitik nasional dan merumuskan geostrategi yang sesuai.

\section{SIMPULAN}

Sriwijaya maupun Melaka memiliki dua karakteristik yang serupa. Mereka memanfaatkan letak geografis mereka untuk meraup keuntungan perdagangan. Hidup dalam berdagang membuat mereka menyadari akan pentingnya suatu organisasi politik yang rapi. Walaupun terdapat beberapa perbedaan siapa saja yang membantu raja atau sultan namun mereka memiliki kemiripan tugas dalam suatu pemerintahan. Hal ini menjadi bukti bahwa Melaka secara tidak langsung telah mewarisi kegemilangan kemaritiman Sriwijaya.

\section{DAFTAR RUJUKAN}

Ahmad, A. D. (1984). Sulatus Salatin (Sejarah Melayu). Kuala Lumpur: Dewan Bahasa \& Pustaka Kementrian Pelajaran Malaysia.

Anas, M., et al. (2017). Pancasila dalam Diskursus: Arus Sejarah, Jalan Tengah, dan Filosofi Bangsa. Yogyakarta: Ifada Publishing.

Andaya, B. W., \& Andaya, L. Y. (1982). A History of Malaysia. Hampshire \& London: Macmillan Education.

Beros, M. (2016). Cosmopolitan Identity - Historical
Origins and Contemporary Relevance. Tabula, 14(1), 199-213.

Budisantoso, H. (2006). Sriwijaya Kerajaan Maritim Terbesar Pertama di Nusantara. Jurnal Ketahanan Nasional, 11(1), 49-56.

Christie, J.W. (1995). State Formation in Early Maritime Southeast Asia; A Consideration of the Theories and the Data. Bijdragen tot de Taal-, Land-en Volkenkunde, 151(2), 235-288.

Claessen, H. J. M. (1995). How Unique Was Srivijaya? Bijdragen tot de Taal-, Land-en Volkenkunde, 151(3), 443-445.

Hall, D. G. E. (1955). A History of South-East Asia. London \& Basingstoke: Macmillan Press

Kartodirdjo, S. (1989). Pemberontakan Petani Banten Tahun 1888. Jakarta: LP3ES.

Kulke, H. (1993). Kadātuan Śrīvijaya-Empire or Kraton of Śrivijaya? A Reassessment of the Epigraphical Evidence. Bulletin de l'École française d'Extrême-Orient, 80(1), 159-180. Lombard, D. (1996). Nusa Jawa: Silang Budaya: Kajian Sejarah Terpadu Jilid 2: Jaringan Asia. Jakarta: Gramedia Pustaka Utama \& Forum Jakarta-Paris (EFEO).

Luttwak, E. (1996). The Grand Strategy of the Roman Empire: From the First Century to the Third Century. London: Weidenfeld and Nicolson.

Luttwak, E. (2009). The Grand Strategy of the Byzantine Empire. Cambridge: Belknap Press. Meilink-Roelofzs, M. A. P. (1970). Asian Trade and European Influence in the Indonesian Archipelago between 1500 and about 1630. Cham: Springer.

Parker, G. (1998). The Grand Strategy of Philip II. New Haven: Yale University Press.

Pires, T. (2010). The Suma Oriental of Tomé Pires: An account of the East, from the Red Sea to Japan, Written in Malacca and India in 1512-1515, and the Book of Francisco Rodrigues, Rutter of a Voyage in the Red Sea, Nautical Rules, Almanack and Maps, Written and Drawn in the East Before 1515. (Cortesão, A, Terjemahan).

Poesponegoro, M. D., \& Notosusanto, N. (2010). Sejarah Nasional Indonesia Jilid 2. Jakarta: Balai Pustaka.

Pradhani, S. I. (2017). Sejarah Hukum Maritim 
Kerajaan Sriwijaya dan Majapahit dalam Hukum Indonesia Kini. Lembaran Sejarah. 13(2), 186-203.

Raffles, S. (1879). The Maritime Code of the Malays. Journal of the Straits Branch of the Royal Asiatic Society, (3), 62-84.

Rizal, J. J. (2017). 100 Tahun Penemuan Sriwijaya. Diakses dari https://tirto.id/100-tahunpenemuan-sriwijaya-cAmQ

Strassler, R. (1996). The Landmark Thucydides: A Comprehensive Guide to the Peloponnesian War. New York: The Free Press.

Villiers, J., \& Earle T.F. (1990). Afonso de Albuquerque, Caesar of the East. Warminster: Aris \& Phillips.

Wade, G. (2009). An Early Age of Commerce in Southeast Asia, 900-1300 CE. Journal of Southeast Asian Studies, 40(2), 221-265.

Wales, H. G. Q. (1978). The Extent of Srivijaya's
Influence Abroad. Journal of the Malaysian Branch of the Royal Asiatic Society, 51(1), 4-11.

Wey, A.L.K \& Harun, A.L. (2018). Grand Strategy of the Malacca Sultanate, 1400 1511. Comparative Strategy, 37(1), 49-55.

Wolters, W. (1966). A Note on the Capital of Śrivijaya during the Eleventh Century. In Essays Offered to G. H. Luce by His Colleagues and Friends in Honour of His Seventy-Fifth Birthday. Edited by Ba Shin, Jean Boisselier, and Alexander B. Griswold, Volume 1: Papers on Asian History, Religion, Languages, Literature, Music Folklore, and Anthropology, pp. 225-239. Ascona: Artibus Asiae.

Zed, M. (2008). Metode Penelitian Kepustakaan. Jakarta: Yayasan Obor Indonesia. 